\title{
Does early acne intervention provide more than just a reduction in the incidence of scars? A review of the literature
}

\section{Ayesha Vos}

\author{
Eastern Health, 8 Arnold Street, Box Hill, VIC, 3128, Australia
}

Corresponding author: Ayesha Vos, MD, E-mail: ayesha.vos@hotmail.com

\begin{abstract}
Background: It is well established that early intervention in acne treatment reduces the incidence of scars. The purpose of this paper was to identify if early intervention in acne management also provides a cost benefit to the patient, reduces relapse rates or lessens the requirement for the treatment of acne scars. Method: A systematic search of The Cochrane Library, MEDLINE and Cumulative Index to Nursing and Allied Health Literature (CINAHL) was performed independently by one reviewer using predefined criteria. Results: Seven articles were identified from the literature - one systematic review, one review article and five expert opinion articles. Although data supports early intervention in acne management, no articles identified whether a cost benefit was also provided, if there was a reduction in the relapse rates or if there was a decreased requirement for the treatment of acne scars. Conclusions: This review identifies an overall lack of published data regarding multiple outcomes for early intervention in acne and allows for the possible identification of areas where primary research would be beneficial.
\end{abstract}

Key words: Acne; early intervention; scarring; cost-benefit; relapse

\section{INTRODUCTION}

Acne is a disease of the pilosebaceous unit resulting in non-inflammatory lesions including microcomedones and comedones as well as inflammatory lesions comprising papules, pustules, nodules and cysts [1]. It is one of the three most common dermatoses in the world with up to $80-90 \%$ of people between the ages of 16 and 20 affected [2]. In severe cases, acne can lead to cutaneous scarring which in most cases, is permanent. The psychological scarring that can result from acne may also be profound [3]. There is thorough evidence to suggest that early initiation of treatment in acne, in particular with isotretinoin, may reduce the incidence and extent of acne scarring [4]. Pursuing early treatment of acne may prevent or reduce psychosocial problems such as issues with self-esteem, social withdrawal, depression and unemployment [5]. Extrapolation of US data shows that acne could be costing up to $\$ 100$ million per year to the Australian community [6] with justification provided given the social, psychological and physical impacts of the condition. There is however, little research on whether early intervention reduces the overall costs of acne treatment and the need for the treatment of scarring. In addition, there also appears to be a lack of concrete knowledge of whether relapse rates of acne are reduced with early intervention. Given the prevalence and significant patient morbidity resulting from acne, it is vital that robust, good-quality research is completed in this area. This review aims to investigate whether early intervention in acne provides a cost-benefit to the patient, reduces the need for treatment of acne scarring and reduces relapse rates.

\section{METHODS}

A systematic search of The Cochrane Library, MEDLINE and Cumulative Index to Nursing and

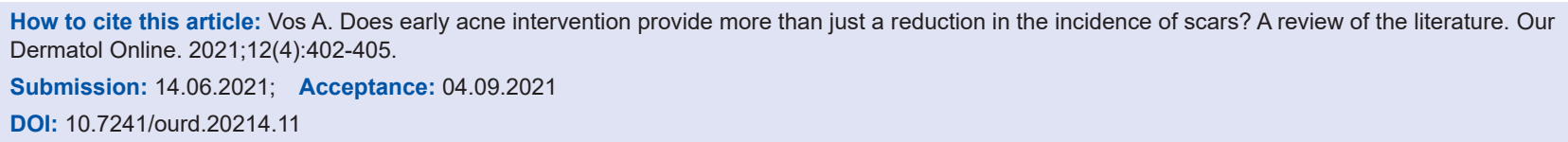


Allied Health Literature (CINAHL) was performed independently by one reviewer using predefined criteria. Key words used in each search engine included acne, early intervention, cost benefit, scarring and relapse. Inclusion criteria included primary research related to early intervention in acne, electronically published literature, articles written in the English language and articles from 1995 onwards. Exclusion criteria included primary research not relating to early intervention in acne, articles not written in the English language, articles published before 1995 and unpublished literature. A total of seven studies were included, which included one systematic review, one review article and five expert opinion articles. The full articles of all studies identified were analysed in depth and can be found in Table I.

\section{RESULTS}

One systematic review, one review article and five expert opinion articles were identified. Whilst ample data was identified to support early intervention in acne to reduce the incidence of scarring, there was no identifiable research found on whether early intervention reduces the need for the treatment of scarring. There was also no identifiable literature on whether early intervention in acne reduces relapse rates or whether it provides a cost benefit to the patient. Studies identified focussed on optimising acne management and patient education in order to reduce the incidence of acne scarring with Bonney et al. (2016) suggesting that acne outcomes can be improved when general practitioners are able to recognise acne scarring early [7]. Layton (2000) argues that isotretinoin instituted early on in the disease course can reduce both the physical and psychological scars that can result from acne [4]. There is evidence to suggest that optimisation of acne management should involve the use of both topical, systemic and localised therapies in order to minimise the development of acne scars [8]. There has also been extensive research performed on the treatment of atrophic scars, the most common

\begin{tabular}{|c|c|c|c|c|c|c|}
\hline $\begin{array}{l}\text { Referencel } \\
\text { Year }\end{array}$ & $\begin{array}{l}\text { Level of } \\
\text { evidence }\end{array}$ & Design & $\begin{array}{l}\text { No. of } \\
\text { patients }\end{array}$ & Major findings & Results/conclusions & Study limitations \\
\hline $\begin{array}{l}\text { Goodman et al. } \\
{[6] / 2006}\end{array}$ & $\mathrm{~N} / \mathrm{A}$ & $\begin{array}{l}\text { Expert } \\
\text { opinion }\end{array}$ & $\mathrm{N} / \mathrm{A}$ & $\begin{array}{l}\text { - Acne is costing } \$ 100 \text { million to } \\
\text { Australian community } \\
\text { - It is expensive to treat a self- } \\
\text { limiting problem } \\
\text { - Affected adolescents report } \\
\text { more social isolation and self- } \\
\text { consciousness, embarrassment, } \\
\text { unhappiness and anxiety than their } \\
\text { unaffected peers } \\
\text { - } 5.6 \% \text { of patients with acne } \\
\text { entertained acute suicidal thoughts } \\
\text { - Scarring may affect up to } 95 \% \text { of } \\
\text { patients and is related to severity } \\
\text { and duration of acne before } \\
\text { adequate therapy is instituted } \\
\text { - Early and effective treatment of } \\
\text { acne is the most appropriate way } \\
\text { to prevent scarring }\end{array}$ & $\begin{array}{l}\text { - Early and aggressive treatment of } \\
\text { acne has positive impacts on the } \\
\text { social, psychological and physical } \\
\text { effects of the condition. }\end{array}$ & - Expert opinion article \\
\hline $\begin{array}{l}\text { Goodman. } \\
\text { [9]/1999 }\end{array}$ & $\mathrm{N} / \mathrm{A}$ & $\begin{array}{l}\text { Expert } \\
\text { opinion }\end{array}$ & $\mathrm{N} / \mathrm{A}$ & $\begin{array}{l}\text { - Scarring can be prevented in } \\
\text { patients by early adequate medical } \\
\text { intervention in the disease course. }\end{array}$ & $\begin{array}{l}\text { - Post acne scarring should warrant } \\
\text { treatment of the earliest, best and } \\
\text { most effective treatments } \\
\text { - Punched out scars benefit from } \\
\text { 'coring of scars' followed by } \\
\text { suturing or graft application } \\
\text { - Dermal and subcutaneous } \\
\text { augmentation methods include } \\
\text { dermal grafting, lipocytic dermal } \\
\text { augmentation, fat transfer and } \\
\text { implantation of autologous collagen } \\
\text { and cultured and expanded } \\
\text { autologous fibroblasts } \\
\text { - Non-autologous augmentation } \\
\text { of atrophic acne scars include } \\
\text { injection of bovine collagen, } \\
\text { fibrin foam, hyaluronic acid } \\
\text { or polymethylmethacrylate } \\
\text { microspheres }\end{array}$ & - Expert opinion article \\
\hline
\end{tabular}


Table I: (Continued)

\begin{tabular}{|c|c|c|c|c|c|c|}
\hline $\begin{array}{l}\text { Reference/ } \\
\text { Year }\end{array}$ & $\begin{array}{l}\text { Level of } \\
\text { evidence }\end{array}$ & Design & $\begin{array}{l}\text { No. of } \\
\text { patients }\end{array}$ & Major findings & Results/conclusions & Study limitations \\
\hline $\begin{array}{l}\text { Layton et al. } \\
{[4] / 2000}\end{array}$ & $\mathrm{~N} / \mathrm{A}$ & $\begin{array}{l}\text { Expert } \\
\text { opinion }\end{array}$ & $\mathrm{N} / \mathrm{A}$ & $\begin{array}{l}\text { - Facial scarring occurs in up to } 95 \% \\
\text { of acne cases } \\
\text { - Less scarring occurred in patients } \\
\text { who received isotretinoin early in } \\
\text { their disease course } \\
\text { - Reduced depression scores } \\
\text { were seen in patients with facial } \\
\text { acne lesions when treated with } \\
\text { isotretinoin. } \\
\text { - Treating acne early on the disease } \\
\text { course reduces clinical scars } \\
\text { - Effective therapy for acne may } \\
\text { reduce psychological and social } \\
\text { issues }\end{array}$ & $\begin{array}{l}\text { - There is an increase in anxiety, } \\
\text { depression and social isolation in } \\
\text { patients who suffer from acne }\end{array}$ & - Expert opinion article \\
\hline $\begin{array}{l}\text { McGoldrick et al. } \\
\text { [10] /2017 }\end{array}$ & N/A & $\begin{array}{l}\text { Expert } \\
\text { opinion }\end{array}$ & N/A & $\begin{array}{l}\text { - Surgical intervention within } 6 \\
\text { months of discontinuing isotretinoin } \\
\text { may result in hypertrophic scarring } \\
\text { - There is level IV evidence } \\
\text { to support dermabrasion, } \\
\text { microdermabrasion, light or } \\
\text { medium-depth chemical peeling } \\
\text { and laser technologies } \\
\text { - The time between onset of effective } \\
\text { treatment and the extent and } \\
\text { duration of inflammation are critical } \\
\text { in acne scar development }\end{array}$ & $\begin{array}{l}\text { - In term of acne scar prophylaxis, } \\
\text { early appropriate medical } \\
\text { treatment that is continued for as } \\
\text { long as necessary is best practice }\end{array}$ & - Expert opinion article \\
\hline $\begin{array}{l}\text { Patel et al. } \\
\text { [3]/2014 }\end{array}$ & $\mathrm{N} / \mathrm{A}$ & $\begin{array}{l}\text { Systematic } \\
\text { review }\end{array}$ & N/A & $\begin{array}{l}\text { - Acne is prevalent in } 90 \% \text { of } \\
\text { adolescent patients } \\
\text { - Acne patients experienced } \\
\text { psychological and emotional } \\
\text { morbidity comparable to conditions } \\
\text { such as epilepsy, diabetes and } \\
\text { chronic pain } \\
\text { - Evidence supports use of laser, } \\
\text { surgery and peel therapy for } \\
\text { atrophic scar treatment } \\
\text { - In the adult population, } 1 \% \text { of } \\
\text { patients are reported to have acne } \\
\text { scarring persisting from adolescence }\end{array}$ & $\begin{array}{l}\text { - CO2 ablative therapy, laser } \\
\text { 1450nm diode laser/Nd YAG } \\
\text { laser have the best evidence to } \\
\text { support their use in atrophic scar } \\
\text { treatment }\end{array}$ & $\begin{array}{l}\text { - GRADE scoring system } \\
\text { = subjective } \\
\text { - Publication bias }\end{array}$ \\
\hline $\begin{array}{l}\text { Savage et al. } \\
{[8] / 2010}\end{array}$ & N/A & $\begin{array}{l}\text { Review } \\
\text { article }\end{array}$ & N/A & $\begin{array}{l}\text { - Patients with acne may have } \\
\text { impaired self-esteem, anxiety and } \\
\text { depression } \\
\text { - Acne can lead to social isolation, } \\
\text { relationship issues and suicidal } \\
\text { ideation } \\
\text { - Early onset of acne, hyper } \\
\text { seborrhoea, truncal acne and } \\
\text { scarring are poor prognostic factors } \\
\text { in acne }\end{array}$ & $\begin{array}{l}\text { - Limiting the duration of active } \\
\text { disease by early and effective } \\
\text { treatment offers the possibility } \\
\text { of minimising both the physical } \\
\text { and emotional scarring caused } \\
\text { by acne } \\
\text { - A focus on early aggressive } \\
\text { intervention is paramount for all } \\
\text { patients to reduce the physical } \\
\text { and psychological scarring that } \\
\text { can result from acne of any } \\
\text { severity }\end{array}$ & - Review article \\
\hline $\begin{array}{l}\text { Torjesen et al. } \\
{[11] / 2019}\end{array}$ & N/A & $\begin{array}{l}\text { Expert } \\
\text { opinion }\end{array}$ & N/A & $\begin{array}{l}\text { - A lack of elastic fibres was seen } \\
\text { from the beginning of acne } \\
\text { inflammation } \\
\text { - A lack of elastic fibres existed in } \\
\text { mature atrophic scars }\end{array}$ & $\begin{array}{l}\text { - TGF-B1 enhances inflammation } \\
\text { and affects fibrosis and epidermal } \\
\text { proliferation } \\
\text { - Anti-inflammatory or anti-TGF } \\
\text { B1 drugs may minimise atrophic } \\
\text { scarring in acne. } \\
\text { - Cutibacterium acne stimulates } \\
\text { TNFa, IL-6, IL-12 and CXCL8 via } \\
\text { toll-like receptor } 2 \text { signalling }\end{array}$ & - Expert opinion article \\
\hline
\end{tabular}

form of scars found in patients with acne. Despite this, further research with randomised controlled trials is necessary to be able to provide sound evidence for the management of atrophic scars [3].

\section{DISCUSSION}

Despite comprehensively and systematically reviewing the literature in an attempt to address our research 
question, knowledge on various outcomes for early intervention in acne management are limited. Our research questions were not answerable using the literature. While there has been much research on the reduction in the incidence of scarring with early intervention, few researchers have delved into whether early intervention reduces the need for treatment of scars. Given the significant patient morbidity of acne, this points to the need for a study involving primary data collection in order to find an answer to whether or not early intervention in acne provides a cost benefit to the patient, reduces the need for treatment of acne scarring and reduces relapse rates. Limitations of our study include the small number of articles retrieved from which we are able to draw a firm conclusion as well as the fact that there is no best approach to comparing qualitative, quantitative and discussion papers. A publication bias was also noted as unpublished literature and literature not written in the English language were excluded. Other sources of limitations include unavailable and inaccessible data.

\section{CONCLUSION}

In summary, this review identifies an overall lack of published data regarding multiple outcomes for early intervention in acne and allows for the possible identification of areas where further primary research would be beneficial. Whilst it is known that isotretinoin, early optimisation of acne management and patient education can reduce the incidence of both the physical and psychological scars of acne, more research needs to be conducted to identify whether early intervention in acne provides a direct cost-benefit to the patient, reduces the need for the treatment of acne scarring and reduces relapse rates.

\section{Statement of Human and Animal Rights}

All the procedures followed were in accordance with the ethical standards of the responsible committee on human experimentation (institutional and national) and with the 2008 revision of the Declaration of Helsinki of 1975.

\section{Statement of Informed Consent}

Informed consent for participation in this study was obtained from all patients.

\section{REFERENCES}

1. Ramasamy S, Barnard E, Dawson TL, Li H. The role of the skin microbiota in acne pathophysiology. Br J Dermatol. 2019;181:691-9.

2. Bagatin E, Costa CS. The use of isotretinoin for acne - an update on optimal dosing, surveillance, and adverse effects. Expert Rev Clin Pharmacol. 2020;13:885-97.

3. Patel L, McGrouther D, Chakrabarty K. Evaluating evidence for atrophic scarring treatment modalities. JRSM Open. 2014;5:1-13.

4. Layton A. Acne scarring - reviewing the need for early treatment of acne. J Dermatol Treat. 2000;11:3-6.

5. Paravina $M$, Stepanović $M$, Štilet $P$, Spasić DJ. Acne vulgaris - Adequate and timely therapy as an early prevention of psychological disturbances. Med Biol. 2019;21:76-80.

6. Goodman G. Acne and acne scarring: the case for active and early intervention. Aust Fam Physician. 2006;35:503-4.

7. Bonney AD, Mullan J, See J, Rayner JE, Hammond A. Investigating GP experiences: Barriers and facilitators to the management and referral of acne patients in a primary care setting. Research Online. 2016;1:1

8. Savage LJ, Layton AM. Treating acne vulgaris: systemic, local and combination therapy. Expert Rev Clin Pharmacol. 2010;3:563-80.

9. Goodman GJ. Acne and acne scarring: why should we treat?. Med J Aust. 1999;171:62-3.

10. McGoldrick RB, Theodorakopoulou E, Azzopardi EA, Murison M. Lasers and ancillary treatments for scar management Part 2: Keloid, hypertrophic, pigmented and acne scars. Scars Burn Heal. 2017;3:1-16.

11. Torjesen I. Early acne intervention may prevent later scarring. Dermatol Times. 2019;40:27.

Copyright by Ayesha Vos. This is an open access article distributed under the terms of the Creative Commons Attribution License, which permits unrestricted use, distribution, and reproduction in any medium, provided the original author and source are credited.

Source of Support: Nil, Conflict of Interest: None declared. 